\title{
Massyles et Massaesyles : note linguistique complémentaire
}

\section{S. Chaker}

\section{(2) OpenEdition}

\section{Journals}

Édition électronique

URL : http://journals.openedition.org/encyclopedieberbere/500

DOI : 10.4000/encyclopedieberbere.500

ISSN : 2262-7197

Éditeur

Peeters Publishers

\section{Édition imprimée}

Date de publication : 29 décembre 2010

Pagination : 4663

ISBN : 978-90-429-2367-6

ISSN : 1015-7344

Référence électronique

S. Chaker, « Massyles et Massaesyles : note linguistique complémentaire », Encyclopédie berbère [En ligne], 30 | 2010, document M56b, mis en ligne le 22 septembre 2020, consulté le 13 octobre 2020. URL : http://journals.openedition.org/encyclopedieberbere/500 ; DOI : https://doi.org/10.4000/ encyclopedieberbere.500

Ce document a été généré automatiquement le 13 octobre 2020.

(c) Tous droits réservés 


\section{Massyles et Massaesyles : note linguistique complémentaire}

\section{S. Chaker}

1 Le nom des Massyles est sans doute à relier au toponyme contemporain Tamsilt (en berbère), Msila (en arabe dialectal). L'actuelle ville de Tamsilt/Msila est située dans la zone massyle antique. Il forme un couple curieux avec Massaesyle*, autre groupe géographiquement contigü. Il n'est pas impossible que ces deux ethnonymes reposent sur la même racine MSL, qui a en berbère des significations diverses :

«façonner, modeler » (kabyle), « frotter (légèrement)/frôler » (touareg)

2 qui semblent toutes pouvoir être ramenées à un même sens de base lié au « mouvement (délicat) de la paume de la main ». Elle est à l'origine de divers nominaux dont certains désignent des végétaux, d'autres le «flanc» (corps humain ou animal).

INDEX

Mots-clés : Antiquité, Ethnonymie, Linguistique, Peuplement, Population, Tribu 